\title{
A new chemically amplified electrochemical system for DNA detection in solution
}

\author{
Chao Li $^{\text {a,b }}$, Shili Liu ${ }^{\text {b,c }}$, Liang-Hong Guo ${ }^{\text {d,* }}$, Depu Chen ${ }^{\text {a }}$ \\ ${ }^{a}$ Department of Chemistry, Tsinghua University, Beijing 100084, PR China \\ ${ }^{\mathrm{b}}$ Beijing National Biochip Research and Engineering Center, 18 Life Science Parkway, Changping District, Beijing 102206, PR China \\ ${ }^{\mathrm{c}}$ Department of Biological Sciences and Biotechnology, Tsinghua University, Beijing 100084, PR China \\ ${ }^{\mathrm{d}}$ Research Center for Eco-environmental Sciences, Chinese Academy of Sciences, 18 Shuangqing Road, Haidian District, Beijing 100085, PR China
}

Received 21 September 2004; received in revised form 13 October 2004; accepted 25 October 2004

Available online 11 November 2004

\begin{abstract}
A newly developed chemically amplified electrochemical detection system was applied to the quantitation of DNA in solution. The system employed $\mathrm{Ru}(\mathrm{bpy})_{2} \mathrm{dppz}$ (bpy = 2,2'-bipyridine, dppz = dipyrido[3,2-a: $\left.: 2^{\prime}, 3^{\prime}-c\right]$ phenazine), a high-affinity DNA intercalator, as the electrochemical indicator, oxalate as the sacrificial electron donor to chemically amplify the electrochemical signal, and tin-doped indium oxide as the working electrode to suppress background current. Intercalation of Ru(bpy) ${ }_{2} \mathrm{dppz}$ into calf thymus DNA in solution led to a reduction in the oxalate-amplified electrochemical current as compared to a DNA-free solution. The degree of reduction was a function of the concentration of DNA, thus forming the basis for DNA detection. To illustrate the advantages of the new system, a direct comparison was made between amplified (with oxalate) and non-amplified (without oxalate) DNA detection. In the presence of $100 \mathrm{mM}$ oxalate, anodic current of $\mathrm{Ru}(\mathrm{bpy})_{2} \mathrm{dppz}$ was amplified by more than 60 folds, resulting in substantial improvement in signal-to-background ratio. Furthermore, as the DNA concentration was increased, the amplified current decayed much faster than the non-amplified signal, giving rise to higher detection sensitivity. The steeper decay was attributed to slower redox reaction between DNA-intercalated $\mathrm{Ru}(\mathrm{bpy})_{2} \mathrm{dppz}$ and oxalate, as the negatively charged phosphate groups on DNA repelled the anions. Effect of ionic strength was investigated to provide support for the interpretation. As expected, the decay of the amplified response with increasing concentration of DNA became less steep when more $\mathrm{NaCl}$ was added into the solution. The opposite effect was observed when tri-propylamine, a cationic electron donor, was used instead of oxalate. With an optimized concentration of $30 \mathrm{mM}$ oxalate and $5 \mu \mathrm{M} \mathrm{Ru}(\mathrm{bpy})_{2} \mathrm{dppz}$, calf thymus DNA of as low as $1 \mathrm{pM}$ was detected in solution, which was close to the detection limit of some fluorescence measurements.
\end{abstract}

(c) 2004 Elsevier B.V. All rights reserved.

Keywords: Electrochemical detection; Chemical amplification; DNA; Intercalation; Ru(bpy) ${ }_{2} \mathrm{dppz}$

\section{Introduction}

We have already entered the post-human genome project era. More genes need to be identified and their cellular functions need to be elucidated. Methods that are rapid and easy to detect and quantify nucleic acids are preferable. Hybridization of nucleic acids to their

\footnotetext{
${ }^{*}$ Corresponding author. Tel./fax: +86 1062849339.

E-mail address: 1hguo@mail.rcees.ac.cn (L.-H. Guo).
}

complementary sequences is the essence of modern molecular biology. The majority of the current methods for the detection of nucleic acid sequence are based on labeling the single strand of interest with a reporter group, most commonly a fluorophore [1]. However, the fluorescence-based methods suffer from the drawback of high cost due to the complex and expensive optical detection instrumentation.

At present, nucleic acid electrochemistry is a booming field [2]. A variety of approaches have been proposed 
and tested for electrochemical detection: (a) detecting the oxidative or reductive current of DNA bases directly $[3,4]$; (b) detecting the anodic current of DNA bases with the aid of a mediator [5-7]; (c) detecting the oxidation of DNA sugar moieties [8]; (d) detecting the electrochemical reaction of a non-covalent DNA binder [917]; (e) detecting the current generated from a covalently linked label inorganic and organic molecules, enzymes, and nanoparticles [18-23]. The advantages of electrochemical devices are their low-cost, fast response, simple design, small dimension and low power requirement. However, the fact that the detected signal from one label is only one or two electrons in the absence of any amplification mechanism, and that the background current is generated from the double-layer charging, severely limit its sensitivity. To improve the sensitivity, signal amplification is a feasible way. As a matter of fact, enzymatic amplification produced the most sensitive DNA detection to date [20].

We recently developed a chemically amplified electrochemical system aimed for the detection of biological affinity reactions such as antibody/antigen and DNA/ DNA binding [24]. The system employs $\mathrm{Ru}(\mathrm{bpy})_{3}$ (bpy $=2,2^{\prime}$-bipyridine) as an electrochemical reporter, oxalate as a sacrificial electron donor, and tin-doped indium oxide (ITO) as working electrode. Oxalate itself produces negligible oxidation current on ITO, but the electrode reaction of $\mathrm{Ru}(\mathrm{bpy})_{3}$ is facile. Its anodic current is amplified in the presence of oxalate in solution due to the redox reaction between the oxidized ruthenium and oxalate, and subsequent regeneration of the reduced ruthenium compound. The new system has obvious advantages when compared with other chemical and enzymatic amplification schemes. Most of previous reports utilized electrochemically reversible species such as ferricyanide or ruthenium hexaamine to chemically amplify amperometric signal in DNA detection $[15,16]$. It is therefore difficult to avoid background current. In contrast, background current from oxalate is very low due to its intrinsically sluggish electrode kinetics on ITO. The label, $\mathrm{Ru}(\mathrm{bpy})_{3}$, and related polypyridyl compounds, are versatile in their structures and redox properties. For instance, their redox potential can be varied by metal substitution and further fine tuned by the ligands. By selecting the right ligand, the label can either be covalently attached to proteins and DNAs [25,26], or bind to DNA by intercalation [27]. Unlike enzyme labels, the compounds are small and stable, therefore suitable for applications with demanding conditions. In this report, we demonstrate the application of the newly developed chemically amplified electrochemical system in the detection of DNA in solution using a DNA intercalator as the signal generator.

DNA binders are small chemical molecules that bind with DNA non-covalently through three modes: (a) electrostatically with the exterior phosphate groups; (b) hydrophobically at the minor grove; (c) intercalatively from the major grove. Among the commonly used DNA binders, transition metal complexes have received a great deal of attention due to their unique photophysical, photochemical and redox properties [27]. As spectroscopic probes, these metal complexes were initially employed in the investigation of DNA structure and function $[28,29]$. More recently, they have been used in the fluorescence detection of DNA with high sensitivity $[30,31]$. Because many of the DNA binders are redoxactive, they have also been employed as electrochemical probes in the detection of DNA. Bard and colleagues $[32,33]$ pioneered the field of electrochemical study of metal complex/DNA interaction, whereas Mikkelsen and others [9-17] used the redox-indicators in the detection of DNA hybridization events on electrode surfaces. The most promising indicators are the metal complexes containing the dipyrido[3,2- $\left.a: 2^{\prime}, 3^{\prime}-c\right]$ phenazine (dppz) ligand, which have been found to intercalate into DNA with high affinity $\left(K=10^{6}-10^{7} \mathrm{M}^{-1}\right)$ due to its extended aromatic structure [29,34]. Not surprisingly, sensitive DNA assays have been reported using $\mathrm{Ru}-$ and Os-dppz complexes as either electrochemical or fluorescent probe $[30,31,35]$.

In our work, Ru(bpy $)_{2}(\mathrm{dppz})$, a high-affinity DNA intercalator, was employed as an electrochemical indicator in the detection of double-stranded DNA in solution. Its electrochemical current was amplified by a sacrificial electron donor, oxalate. Similar to the observation described by Carter et al. [32,33], intercalation of the metal complex into DNA led to a reduction of the catalyzed current due to slower mass diffusion. However, because the signal was amplified, the signalto-background (S/B) ratio was higher than the non-amplified detection. More significantly, electrostatic repulsion between DNA and oxalate resulted in further reduction on the relative basis, which did not exist in the non-amplified system. By the combination of high-affinity intercalator and amplified electrochemical method, $1 \mathrm{pM}$ ds-DNA was detected in solution.

\section{Experimental}

Sodium oxalate was purchased from Avocado Research Chemicals (Lancaster, PA, USA), oxalic acid from VAS Lab Supplies (Tianjin, PR China), tri- $n$-propylamine (TPA) from Alfa Aesar (Ward Hill, MA, USA). Calf thymus DNA (approximately $13 \mathrm{k}$ base pairs) was obtained from Sigma Chemical Co (St. Louis, MO, USA) and used as received. DNA solution in 100 $\mathrm{mM}$ phosphate buffer, $\mathrm{pH} 5.8$, gave an UV absorption ratio A260/A280 of about 1.8-1.9, indicating the DNA sample was free of protein. Ru(bpy $)_{2} \mathrm{dppz}$ was synthesized according to the published procedure [36,37]. Solutions were prepared in high-purity water from a 
Millipore milli-Q water purification system. The supporting electrolyte was $100 \mathrm{mM}$ phosphate buffer, $\mathrm{pH}$ 5.8, unless otherwise noted. ITO conductive glass was obtained from Weiguang Corporation (Shenzhen, PR China), and was cut into size $2 \times 0.5 \mathrm{~cm}$ electrodes. The electrodes were cleaned in an ultrasonic cleaner sequentially with each of the following solutions: household detergent in water $(15 \mathrm{~min})$, deionized water (2 $\mathrm{min}$, twice), acetone (5 $\mathrm{min})$, isopropanol ( $5 \mathrm{~min}$ ), and deionized water (10 min, twice). Electrochemical measurements were performed on a CHI 660 Electrochemistry Analyzer with a $\mathrm{Pt}$ counter electrode and an $\mathrm{Ag} /$ $\mathrm{AgCl}$ reference electrode. The electrode area in contact with the electrolyte was $0.5 \mathrm{~cm}^{2}$.

\section{Results and discussion}

Interaction of metal complexes with DNA has been studied by cyclic voltammetry in Bard's and Thorp's group $[32,33,38,39]$. The studies were based on the change of the voltammograms of the metal complex after binding with DNA. Basically, voltammetric peak current diminished due to slower mass diffusion of the much larger DNA/metal complex adduct, and the midpoint potential shifted as a result of different DNA binding strength between the two redox states of the metal complex. In principle, the attenuation could be used in the detection of DNA in solution. But sensitivity would be a problem. This is because in simple voltammetric detection on a conventional electrode, the concentration of redox species needs to be no less than micromolar to give adequate $\mathrm{S} / \mathrm{B}$ ratio. As a result, DNA concentration has to be relatively high to bring about noticeable change in current. For instance, with $0.1 \mathrm{mM} \mathrm{Co-}$ (phen) $)_{3}, 0.5 \mathrm{mM}$ calf thymus DNA was needed to produce about $40 \%$ reduction in current [32], although less DNA was required when a stronger intercalator Os(bpy $)_{2}$ dppz was used [39]. Electrochemical detection with chemical amplification mechanism has the potential of improving the signal-to-background ratio. We have shown in our previous study [24] that the oxidation current of $\mathrm{Ru}(\mathrm{bpy})_{3}$ was amplified by more than 1000 fold in an oxalate solution. Therefore, one could use much less DNA binder but with amplification would get comparable signal. This would in turn lower the concentration of DNA that can be detected.

$\mathrm{Ru}(\mathrm{bpy})_{2} \mathrm{dppz}$ was selected in the present study as a DNA intercalating electrochemical indicator for two reasons. One is that metal complexes with dppz ligand have the highest binding constant to date, with $K=10^{6}-10^{7} \mathrm{M}^{-1}[29,34]$. The other reason is that the formal potential of $\mathrm{Ru}(\mathrm{bpy})_{2} \mathrm{dppz}$ is as high as that of $\mathrm{Ru}(\mathrm{bpy})_{3}$. It has been found that there is a good correlation between amplification efficiency and formal potential [24]. The voltammograms in Fig. 1 demon-
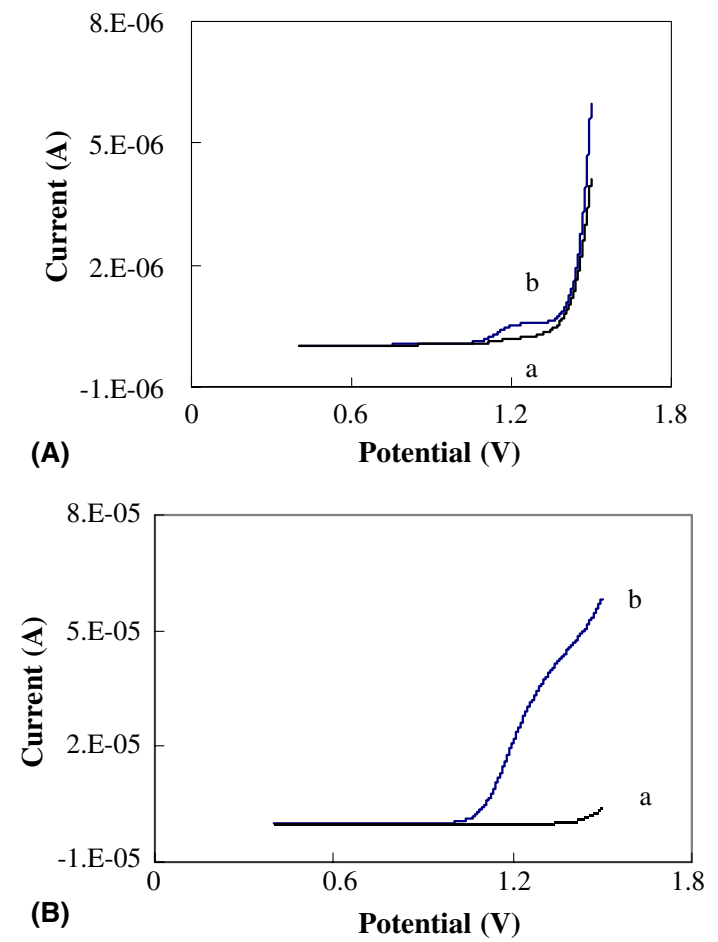

Fig. 1. (A) Cyclic voltammograms of ITO electrodes in: (a) $0.1 \mathrm{M}$ phosphate buffer, pH 5.8; (b) with addition of $5 \mu \mathrm{M} \mathrm{Ru}(\mathrm{bpy})_{2} \mathrm{dppz}$. (B) Cyclic voltammograms of ITO electrodes in: (a) $0.1 \mathrm{M}$ oxalate $/ 0.1 \mathrm{M}$ phosphate, $\mathrm{pH} 5.8$; (b) with addition of $5 \mu \mathrm{M} \mathrm{Ru}(\mathrm{bpy})_{2} \mathrm{dppz}$. Scan rate $10 \mathrm{mV} / \mathrm{s}$. Reference electrode $\mathrm{Ag} / \mathrm{AgCl}$.

strate the power of chemical amplification. Without amplification, anodic peak of $5 \mu \mathrm{M} \mathrm{Ru}(\mathrm{bpy})_{2} \mathrm{dppz}$ at $1.25 \mathrm{~V}$ is marginally distinguishable from the background current (Fig. 1(A)). In contrast, in the presence of $100 \mathrm{mM}$ oxalate, a substantial rise of current was clearly visible starting from $1.0 \mathrm{~V}$ (Fig. 1(B)). Measured at $1.25 \mathrm{~V}$, the current was amplified by 60 folds, leading to much higher $\mathrm{S} / \mathrm{B}$ ratio.

The chemical amplification system not only increased $\mathrm{S} / \mathrm{B}$ ratio, but also improved the sensitivity. This is illustrated by a direct comparison between non-amplified and amplified detection of DNA in solution. In an oxalate-free electrolyte, the anodic current of $5 \mu \mathrm{M} \mathrm{Ru}-$ (bpy) $)_{2} \mathrm{dppz}$ dropped by only $40 \%$ after addition of 4 $\mu \mathrm{M}$ DNA (Fig. 2). In $100 \mathrm{mM}$ oxalate, however, the drop was almost $70 \%$ for the same amount of DNA (Fig. 3). A series of DNA concentrations were measured in both oxalate-free and oxalate-containing electrolyte, and the results are summarized in a plot in Fig. 4. As shown very clearly, when DNA concentration was increased, electrochemical current of the intercalator diminished in both cases. But the amplified response decreased at a much faster rate than the non-amplified current. This suggests that lower concentrations of DNA can be detected by the chemical amplification system.

The faster decay was somewhat unexpected. If slower mass diffusion was the only reason for the drop of 


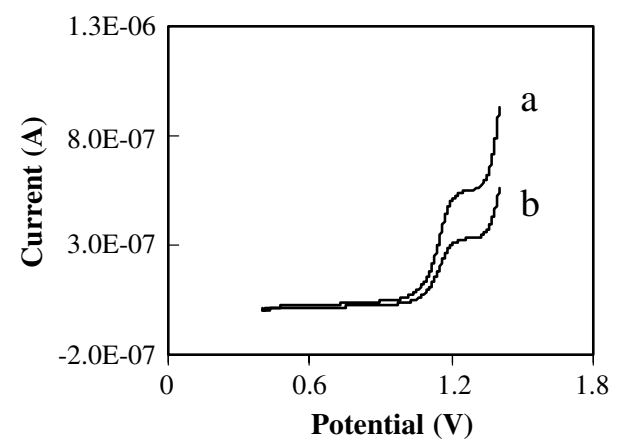

Fig. 2. Cyclic voltammograms of $5 \mu \mathrm{M} \mathrm{Ru}(\mathrm{bpy})_{2} \mathrm{dppz}$ in $0.1 \mathrm{M}$ phosphate buffer, pH 5.8: (a) in the absence of DNA; (b) in the presence of $4 \mu \mathrm{M}$ calf thymus DNA. Scan rate $10 \mathrm{mV} / \mathrm{s}$. Reference electrode $\mathrm{Ag} / \mathrm{AgCl}$.

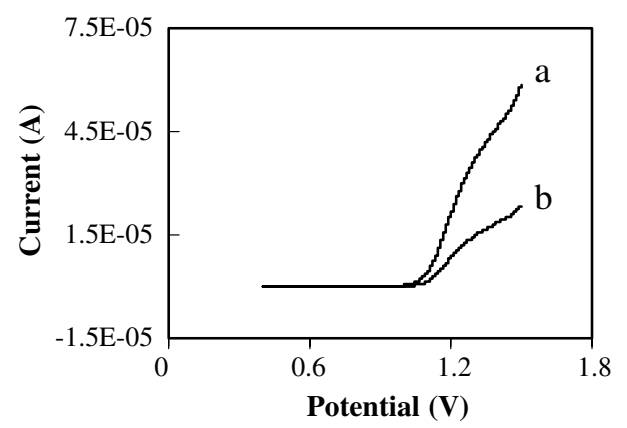

Fig. 3. Cyclic voltammograms of $5 \mu \mathrm{M} \mathrm{Ru}(\mathrm{bpy})_{2} \mathrm{dppz}$ in $100 \mathrm{mM}$ sodium oxalate/0.1 M phosphate buffer, $\mathrm{pH}$ 5.8: (a) in the absence of DNA; (b) in the presence of $4 \mu \mathrm{M}$ calf thymus DNA. Scan rate $10 \mathrm{mV} /$ s. Reference electrode $\mathrm{Ag} / \mathrm{AgCl}$.

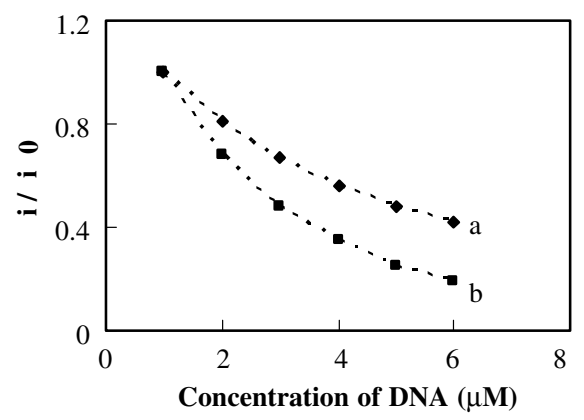

Fig. 4. Plots of normalized anodic current $\left(i / i_{0}\right)$ for $5 \mu \mathrm{M} \mathrm{Ru}$ (bpy) $)_{2} \mathrm{dppz}$ as a function of calf thymus DNA concentration measured in: (a) $0.1 \mathrm{M}$ phosphate buffer, $\mathrm{pH} 5.8$; (b) $100 \mathrm{mM}$ sodium oxalate/0.1 $\mathrm{M}$ phosphate buffer, $\mathrm{pH}$ 5.8. $i_{0}$ current measured before addition of DNA; $i$ current measured after addition of DNA. Scan rate $10 \mathrm{mV} / \mathrm{s}$. Reference electrode $\mathrm{Ag} / \mathrm{AgCl}$.

current, one would have expected the rate of drop to be similar between amplified and non-amplified detection. The fact that the current diminished faster in oxalate suggests another attenuation mechanism was also playing a role. A plausible hypothesis would be the electrostatic repulsion between the oxalate anions and negatively charged phosphate groups on DNA, which would slow down the electron exchange reaction between oxalate and the ruthenium complex intercalated into the DNA interior relative to the free complex. To obtain further experimental evidence to support the hypothesis, the ionic strength effect on the chemically amplified electrochemical detection of DNA was investigated. The experiment depicted in Fig. 4(a) was repeated in $100 \mathrm{mM}$ oxalate, with the ionic strength of the electrolyte increased stepwise by addition of $\mathrm{NaCl}$ into 10 $\mathrm{mM}$ phosphate. As shown in Fig. 5, regardless of the amount of $\mathrm{NaCl}$ added, oxalate-amplified current decreased with increasing concentration of DNA. However, the decrease became progressively less as more $\mathrm{NaCl}$ was added into the oxalate solution. The data are consistent with the assumption of the charge effect in that the electrostatic repulsion would be reduced in high ionic strength buffer.

In another experiment, tri-propylamine (TPA) was used instead of oxalate as the reductant. The data summarized in Fig. 6 shows the ionic strength effect was just the opposite of oxalate. As with oxalate, TPA-amplified current decreased with increasing concentration of

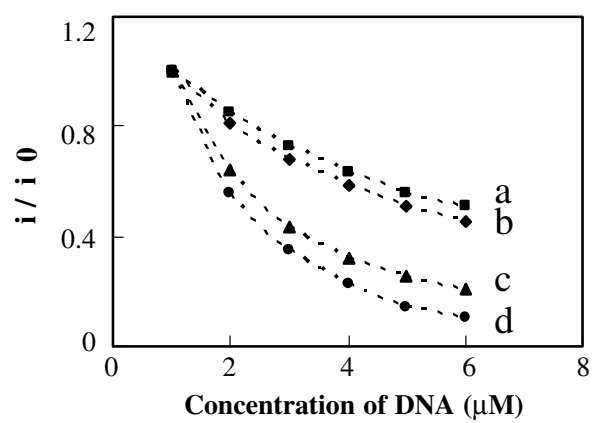

Fig. 5. Plots of normalized anodic current for $5 \mu \mathrm{M} \mathrm{Ru}(\mathrm{bpy})_{2} \mathrm{dppz}$ measured in $100 \mathrm{mM}$ sodium oxalate $/ 10 \mathrm{mM}$ phosphate buffer, $\mathrm{pH} 5.8$ as a function of calf thymus DNA concentration with addition of: (a) 1 M; (b) $0.3 \mathrm{M}$; (c) $0.1 \mathrm{M}$; (d) $0 \mathrm{M} \mathrm{NaCl}$. Scan rate $10 \mathrm{mV} / \mathrm{s}$. Reference electrode $\mathrm{Ag} / \mathrm{AgCl}$.

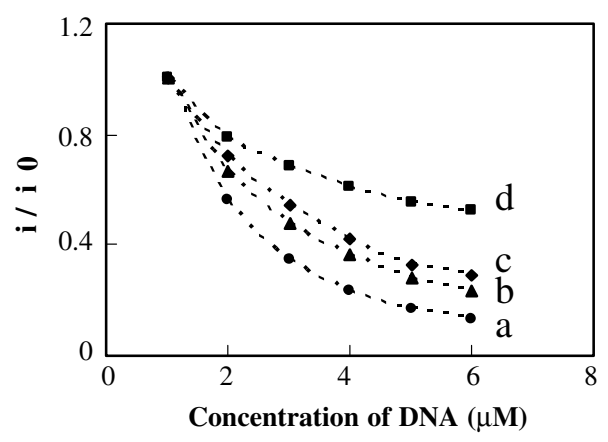

Fig. 6. Plots of normalized anodic current for $5 \mu \mathrm{M} \mathrm{Ru}(b p y)_{2} \mathrm{dppz}$ measured in $10 \mathrm{mM}$ TPA/10 mM phosphate buffer, $\mathrm{pH} 7.5$ as a function of calf thymus DNA concentration with addition of: (a) $1 \mathrm{M}$; (b) $0.3 \mathrm{M}$; (c) $0.1 \mathrm{M}$; (d) $0 \mathrm{M} \mathrm{NaCl}$. Scan rate $10 \mathrm{mV} / \mathrm{s}$. Reference electrode $\mathrm{Ag} / \mathrm{AgCl}$. 
DNA. But the drop became steeper as more $\mathrm{NaCl}$ was added into the solution. At $\mathrm{pH} 7.5$, TPA is a cation. The electrostatic attraction between TPA and DNA phosphates would enhance its redox reaction with intercalated $\mathrm{Ru}(\mathrm{bpy})_{2} \mathrm{dppz}$. The enhancement would partially offset the decrease of current caused by the slower mass diffusion of the intercalated complex. When the ionic strength was increased, the enhancement effect would be reduced, leading to faster decrease of the signal with increasing DNA concentration. So qualitatively both oxalate and TPA data are consistent with the charge effect hypothesis.

When considered separately, the observed ionic strength effect in oxalate and TPA could have been due to something other than the charge effect. For instance, addition of $\mathrm{NaCl}$ might have affected the interaction between $\mathrm{Ru}(\mathrm{bpy})_{2} \mathrm{dppz}$ and DNA, and changed the electrochemical current. But this would change the current of the two reductants in the same direction, not the opposite direction. Ling et al. [40] have investigated the effect of $\mathrm{NaCl}$ on the fluorescence intensity of DNA$\mathrm{Ru}(\mathrm{bpy})_{2} \mathrm{dppx}$ (dppx $=7,8$-dimethyldipyridophenazine) adduct, and found the signal was unchanged up to 150 $\mathrm{mM} \mathrm{NaCl}$. Therefore, it is more likely that the ionic strength effect observed in our experiments was on the electrostatic interaction of DNA with the reductant, not the intercalator. As a matter of fact, this type of charge effect on the redox chemistry between ruthenium polypyridyl complexes and reductants has been previously reported. For example, when Ru(bpy) ${ }_{3}$ was immobilized in a positively-charged chitosan polymer matrix, its selectivity towards oxalate was enhanced relative to TPA as a result of the electrostatic attraction between the positive charges on the polymer and the oxalate anions [41].

Obviously, when oxalate is used as the electron donor, the ionic strength of the buffer for the electrochemical detection should be as low as possible to obtain high sensitivity. On the other hand, we have found that the amplification efficiency increased with oxalate concen-

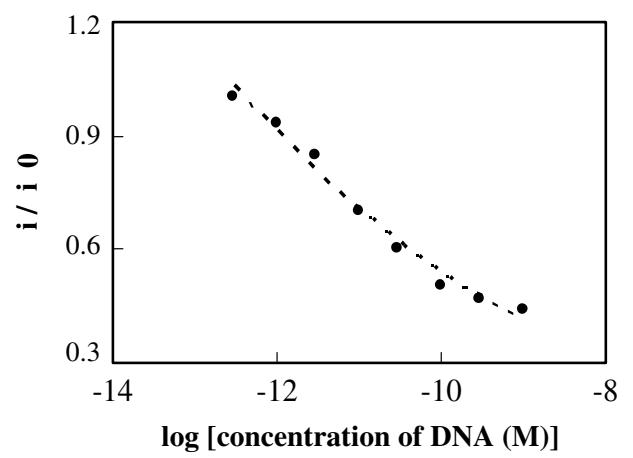

Fig. 7. Plot of normalized anodic current for $5 \mu \mathrm{M} \mathrm{Ru}(b p y)_{2} \mathrm{dppz}$ as a function of calf thymus DNA concentration measured in $30 \mathrm{mM}$ sodium oxalate/oxalic acid buffer, $\mathrm{pH}$ 5.8. Scan rate $10 \mathrm{mV} / \mathrm{s}$. Reference electrode $\mathrm{Ag} / \mathrm{AgCl}$. tration up to $100 \mathrm{mM}$ (data not shown). To maximize oxalate concentration and minimize ionic strength for the best sensitivity, oxalic acid and sodium oxalate were mixed to make a $\mathrm{pH} 5.8$ buffer solution without any other salt. Calf thymus DNA was detected in the presence of $5 \mu \mathrm{M} \mathrm{Ru}(\mathrm{bpy})_{2} \mathrm{dppz}$ in a series of oxalate/oxalic acid solutions ranging from 10,30,100 to $200 \mathrm{mM}$. The results obtained in $30 \mathrm{mM}$ solution, as depicted in Fig. 7 , have the best sensitivity. Addition of even $1 \mathrm{pM}$ DNA into $5 \mu \mathrm{M} \mathrm{Ru}(\mathrm{bpy})_{2} \mathrm{dppz}$ led to about $10 \%$ drop of current, which can be easily detected. This level of detection limit for DNA is comparable to those obtained by fluorescence measurement [30,31], but with much simpler instrumentation.

\section{Conclusions}

The newly developed chemically amplified electrochemical system was applied to the detection of DNA in solution with a DNA intercalator as the signal generator. Compared with the conventional, non-amplified detection, the new system not only improved the S/B ratio because of the amplified current, but more importantly provided very high sensitivity as a result of additional signal attenuation mechanism due to the charge-charge interaction between DNA and the sacrificial electron donor, oxalate. The detection limit of $1 \mathrm{pM}$ DNA is close to some of the reported fluorescence measurements, and is low enough to be used in post-separation detection such as capillary electrophoresis.

\section{Acknowledgements}

This work was supported by the National Hi-Tech Program (Contract No. 2002AA2Z2011) and a startup fund from the Chinese Academy of Sciences.

\section{References}

[1] L.J. Kricka, Ligand-Binder Assays: Labels and Analytical Strategies, Maecel Dekker, New York, 1985.

[2] A. Brajter-Toth, J.Q. Chambers, Electroanalytical Methods of Biological Materials, Marcel Dekker, New York, 2002.

[3] E. Palecek, Nature 188 (1960) 656.

[4] J. Wang, S. Bollo, J.L.L. Paz, E. Sahlin, B. Mukherjee, Anal. Chem. 71 (1999) 1910.

[5] H.H. Thorp, Trends Biotechnol. 16 (1998) 117.

[6] A. Mugweru, J.F. Rusling, Anal. Chem. 74 (2002) 4044.

[7] A. Dennany, R.J. Forster, J.F. Rusling, J. Am. Chem. Soc. 125 (2003) 5213.

[8] P. Singhal, W.G. Kuhr, Anal. Chem. 69 (1997) 4828.

[9] K.M. Millan, S.R. Mikkelsen, Anal. Chem. 65 (1993) 2317.

[10] K.M. Millan, A. Saraullo, S.R. Mikkelsen, Anal. Chem. 66 (1994) 2943.

[11] J. Wang, X. Cai, G. rivas, H. Shiraishi, P.A.M. Farias, N. Dontha, Anal. Chem. 68 (1996) 2629. 
[12] A.B. Steel, T.M. Herne, M.J. Tarlov, Anal. Chem. 70 (1998) 4670.

[13] K. Hashimoto, K. Ito, Y. Ishimori, Anal. Chem. 66 (1994) 3830.

[14] T. Ihara, M. Nakayama, M. Murata, K. Nakano, M. Maeda, Chem. Commun. (1997) 1609.

[15] E.M. Boon, D.M. Ceres, T.G. Drummond, M.G. Hill, J.K. Barton, Nat. Biotechnol. 18 (2000) 1096.

[16] M.A. Lapierre, M. O'Keefe, B.J. Taft, S.O. Kelley, Anal. Chem. 75 (2003) 6327.

[17] P. de-los-SantosAlvarez, P. Rodriguez-Granda, M.J. Lobo-Castanon, A.J. Miranda-Ordieres, P. Tunon-Blanco, Electrochem. Commun. 267 (2003) 271.

[18] T.J. Meade, J.F. Kayyem, Angew. Chem., Int. Ed. Engl. 34 (1995) 352.

[19] C.J. Yu, Y. Wan, H. Yowanto, J. Li, C. Tao, M.D. James, C.L. Tan, G.F. Blackburn, T.J. Meade, J. Am. Chem. Soc. 123 (2001) 11155.

[20] Y. Zhang, A. Pothukuchy, W. Shin, Y. Kim, A. Heller, Anal. Chem. 76 (2004) 4093.

[21] M. Nakayama, T. Ihara, K. Nakano, M. Maeda, Talanta 56 (2002) 857.

[22] J. Wang, J. Li, A.J. Baca, J. Hu, F. Zhou, W. Yan, D.-W. Pang, Anal. Chem. 75 (2003) 3941.

[23] E. Katz, I. Willner, J. Wang, Electroanal 16 (2004) 19.

[24] D. Zheng, N. Wang, F.-Q. Wang, D. Dong, Y.-G. Li, X.-Q. Yang, J. Cheng, L.-H. Guo, Anal. Chim. Acta 508 (2004) 225.

[25] G.F. Blackburn, H.P. Shah, J.H. Kenten, J. Leland, R.A. Kamin, J. Link, J. Peterman, M.J. Powell, A. Shah, D.B. Talley, S.K. Tyagi, E. Wilkins, T.-G. Wu, R.J. Massey, Clin. Chem. 37 (1991) 1534.
[26] J.H. Kenten, S. Gudibande, J. Link, J.J. Willey, B. Curfman, E.O. Major, R.J. Massey, Clin. Chem. 38 (1992) 873.

[27] K.E. Erkkila, D.T. Odom, J.K. Barton, Chem. Rev. 99 (1999) 2777.

[28] J.K. Barton, Science 233 (1986) 727.

[29] A.E. Friedman, J.-C. Chambron, J.P. Sauvage, N.J. Turro, J.K. Barton, J. Am. Chem. Soc. 112 (1990) 4960.

[30] L.-S. Ling, Z.-K. He, G.-W. Song, H.-Y. Han, H.-S. Zhang, Y.E. Zeng, Mikrochim. Acta 134 (2000) 57.

[31] L.-S. Ling, Z.-K. He, G.-W. Song, Y.-E. Zeng, C. Wang, C.-L. Bai, X.-D. Chen, P. Shen, Anal. Chim. Acta 436 (2001) 207.

[32] M.T. Carter, A.J. Bard, J. Am. Chem. Soc. 109 (1987) 7528.

[33] M.T. Carter, M. Rodriguez, A.J. Bard, J. Am. Chem. Soc. 111 (1989) 8901.

[34] K. Maruyama, Y. Mishima, K. Minagawa, J. Motonaka, J. Electroanal. Chem. 510 (2001) 96.

[35] K. Maruyama, Y. Mishima, K. Minagawa, J. Motonaka, Anal. Chem. 74 (2002) 3698.

[36] S. Musumeci, F.S. Rizzarelli, S. Sammartano, R.P. Bonomo, Inorg. Chim. Acta. 7 (1973) 660.

[37] A. Edmond, H. Abdulrazzak, J. Chem. Soc., Dalton Trans. (1990) 841.

[38] M. Rodriguez, A.J. Bard, Anal. Chem. 62 (1990) 2658.

[39] T.W. Welch, A.H. Corbett, H.H. Thorp, J. Phys. Chem. 99 (1995) 11757.

[40] L.-S. Ling, Z.-K. He, Y.-E. Zeng, Spectrochim. Acta Part A 55 (1999) 1297.

[41] C.-Z. Zhao, N. Egashira, Y. Kurauchi, K. Ohga, Electrochim. Acta 43 (1998) 2167. 